\title{
Development of Learning Media Using VideoScribe for the Subject of Present Continuous Tense
}

\author{
Pahmi $^{1]}$, Wandi Syahfutra ${ }^{2]}$ \\ Universitas Muhammadiyah Riau \\ E-mail: ${ }^{1]}$ pahmi@umri.ac.id \\ ${ }^{2]}$ wandisyahfutra@umri.ac.id
}

\begin{abstract}
To master English, students must learn many things, including about grammar in order to use English properly and correctly. There are a number of ways lecturers can do to support teaching and learning process, one of which is by making use of technology to develop learning media. Using media is expected to make learning process about grammar enjoyable. This research aims to develop learning media using VideoScribe for the subject of Present Continuous Tense which is one of the materials studied by odd semester students at Universitas Muhammadiyah Riau. This research further designs, implements and tests the feasibility of the learning media. This research is a research and development (R\&D) model with ADDIE which consists of 5 stages, namely Analysis, Design, Development, Implementation and Evaluation. The subjects of this study were undergraduate students majoring in non-English Department which consisted of 35 students in odd semester. The results of alpha testing, expert material assessment showed that the media that were designed was in a very good category with an average score of 4.26. Meanwhile, for trials with students, the video animation media using VideoScribe was in a very good category with an average score of 4.25. Therefore, it can be concluded that the instructional media designed is suitable to be used to support teaching and learning activities.
\end{abstract}

Keywords: Learning Media, VideoScribe, Present Continuous Tense

\section{Pengembangan Media Pembelajaran menggunakan VideoScribe untuk Materi Present Continuous Tense}

\begin{abstract}
Abstrak
Untuk menguasai Bahasa Inggris, siswa harus mempelajari banyak hal, termasuk tentang tata bahasa agar bisa menggunakan Bahasa Inggris dengan baik dan benar. Ada banyak cara yang dilakukan dosen untuk mendukung kegiatan belajar mengajar, salah satunya adalah dengan memanfa'atkan teknologi untuk mengembangkan media pembelajaran. Penggunaan media diharapkan bisa membuat proses belajar mengajar tentang tata bahasa menjadi menyenangkan. Penelitian ini bertujuan untuk mengembangkan media pembelajaran menggunakan VideoScribe untuk pokok bahasan Present Continuous Tense yang menjadi salah satu materi yang dipelajari mahasiswa
\end{abstract}


semester ganjil di Universitas Muhammadiyah Riau. Penelitian ini lebih jauh merancang, mengimplementasikan serta menguji kelayakan media pembelajaran tersebut. Penelitian ini merupakan penelitian pengembangan $(R \& D)$ dengan model ADDIE yang terdiri dari 5 tahapan, yaitu Analysis (Analisis), Design (Perancangan), Development (Pengembangan), Implementation (Implementasi) dan Evaluation (Evaluasi). Subjek dari penelitian ini adalah mahasiswa S1 jurusan bukan Bahasa Inggris yang terdiri dari 35 mahasiswa pada semester ganjil. Hasil dari pengujian alpha testing, penilaian ahli materi menunjukkan bahwa media yang di rancang termasuk dalam kategori sangat baik dengan rata-rata skor 4,26. Sementara itu untuk uji coba dengan peserta didik, media animasi video menggunakan VideoScribe ini mendapatkan kategori sangat baik dengan rata-rata skor 4,25. Oleh karena itu, dapat disimpulkan bahwa media pembelajaran yang dirancang ini layak digunakan untuk mendukung kegiatan belajar mengajar.

Kata Kunci: Learning Media, VideoScribe, Present Continuous Tense

\section{INTRODUCTION}

English is a compulsory subject in Indonesian schools. Apart from the government policy, each person must have reason to learn English. The reasons may vary for each individual, but the most common one can be due to globalization era. It is a fact that most people need to learn English because they often have to deal with English in all aspects of life. It is used in "research, publication, business and commerce" (Mappiasse \& Sihes, 2014) in this globalization era.

Furthermore, mastering English is inevitable since it brings many advantages to support people's life. No matter what profession someone has, h/she needs to learn English. In order to master English, students should learn four skills (listening, speaking, reading and writing) as well as the other supporting aspects such as vocabulary, grammar, and so forth. Grammar itself is an important component in language learning because it is one of the basic knowledge in order to be able to use English accurately.
In Indonesia, English is learnt not only by school students but also by higher education students and even employees. However, Indonesian students often face difficulty to use English in daily communication even though they have been studying it for a long time.

In Universitas Muhammadiyah Riau (UMRI), all freshmen are required to take General English subject in the $1^{\text {st }}$ semester. This is to prepare the students to have language competence to support their future life. The students are from twenty departments in UMRI. They have various levels of English capability. In teaching General English, the institution provides several books as reference. One of the books the lecturer mostly uses is Interchange (Fifth Edition) by Richards, Hull \& Proctor (2017). The course is conversationbased where the students are trained to improve their speaking skill. Even though it is conversation class, grammar is still included. Since it is conversation class, the lecturers are expected to find ways to teach grammar in a communicative way which allows the 
students to speak English more during the lesson.

Grammar is defined as rules underlying a language that govern the structure of words, clauses and sentences (Cross, 1991, p. 26 as cited in Ong, 2011). Mastering the rules becomes a challenge for English learners since the rules are many. However, this cannot be avoided in that knowing the rules will enable the learners to know the correct way to convey ideas. In other words, the learners can use English in daily communication accurately. Grammar can also be defined as how the words are transformed into another form and grouped together into sentences (Harmer in Heryanti, Sucipto, \& Makmur, 2017:84). Moreover, Bury Thorn (1999) in Guterres \& Soares (2017:165) states that "grammar is a part the study of what forms (or structures) are possible in a language".

\section{English Tenses}

Tenses refers to the time of an action, event or state (Guterres \& Soares, 2017). In addition, Nofriani (2016) in Megawati (2019:44) asserted that tenses are about verbs relating to time. The verbs indicate in general the action: present tense (e.g. the student studies), past tense (e.g. the student studied), and future tense (e.g. the student will study). Mastering tenses will enable the students to know when the time of action occurs, and understand the correspondence between the form of the verb and their concept of time.

In talking about tense, it is not only focused on the time of the situation that is being described, but discusses about form of verb. Almost all verbs can show the differences between the present, past and the future time by changing in the verb form.
The students enrolling General English subject focus on mastering six important tenses, namely simple present, present continuous, present perfect, present perfect continuous, simple past, and simple future. However, this study focuses on using present continuous tense as sample material to be used in the development of animated video learning media using VideoScribe.

The present continuous tense is construction which is made of subject + auxiliary verb (verb) + main verb (base + ing). It is used to indicate an action that one uses. In addition, it is used to talk about: action happening now, and action happening in the future. The present continuous tense is called the real present, in the sense that it can be demonstrated. The present continuous tense describes an action which goes on at the moment of speaking. It can be used to describe an action which goes on in more general present, not necessary at the moment of speaking. And it is formed with the appropriate present form (is, am, are) and the verb ending in - ing.

Azar \& Hagen (2017) in their book entitled Understanding and Using English Grammar described that the Present Continuous tense expresses an activity which is in the progress at the moment of speaking. The following is more explanation about present continuous tense.

The Present Continuous Tense is formed with the present tense of be, verb be + the present participle. There are three kinds of sentences which can be used in present continuous tense.

The formula can be seen as follows:

a. Positive Sentences

To make positive sentences, the following formula is used: 
Subject+ Be (am + are+ is $)+$ PRESENT PARTICIPLE (ingform)

For example:

- I am studying English now

- The teacher is teaching right now

- My parents are talking at the moment

b. Negative Sentences

To make negative sentences, it uses the following formula:

Subjec+ Be (am + are+ is $)+$

NOT + PRESENT

PARTICIPLE (ing-form)

For example:

- I am not studying English now

- The male student is not eating lunch at the moment

- The university students are not discussing about the Internet, but about religion

c. Interrogative Sentences

To make interrogative sentences, it uses the following formula:

$\mathrm{Be}(\mathrm{am}+\mathrm{are}+\mathrm{is})+$ Subject + PRESENT PARTICIPLE (ingform)

For example:

- Are you studying English now?

- Is your daughter studying at UMRI?

Based on the author's experience, many students find grammar, including present continuous tense, difficult and even boring. Furthermore, the research finding by (Pahmi \& Edjuista, 2018) showed that many students often make grammar mistakes in speaking and writing. For example, the students forget to add s/es for the verb in Simple Present Tense, or they often use the base form of verb in talking about something happening now. For example they say, "My friend go to the school". This sentence should be, "My friend goes to school". In another situation, they say, "I am study now" which is supposed to be "I am studying now".

This demonstrates how mastering tenses becomes a challenge for many learners. They are often still confused to use which tenses during speaking activities. As a result, they cannot convey their ideas in a grammatically correct way.

There are some factors why such situation can occur. First, many lecturers still teach English specifically grammar in a conventional way where they just explain the rules and do some exercises. The limited learning media to help the student master grammar and foster their interest is also an obstacle. Therefore, the lecturers need to find a variety of ways to tackle this issue.

One effort that can be done is to develop learning media by making use of VideoScribe that can help student master grammar in a fun way. In teaching, many teachers normally present the material using the book. Sometimes they use PowerPoint, present the key points, lead a discussion, and facilitate the conversation activity for the students. The students' access to the material is only from reading the book at home and discussing in the face-to-face meeting. That is why creating the animated video can give new experiences for the students both outside and inside the classroom.

Today's learning can be enriched by making use of the development of Information and Communications Technology (ICT). As known that ICT has transformed how classroom works (Kozma and Anderson, 2002 as cited by Ghavifekr et al., 2014). 
Many teachers have been aware and tried to integrate ICT in teaching and learning process. According to Nordin, Embi \& Yunus (2010), ICTs refer to technological tools and resources utilized to communicate, create, disseminate and manage information.

There are a number of advantages in using ICT to support teaching and learning. First, teachers can plan and design appropriate teaching method. They further can create a learning environment for the learners. This can prepare the learners in a real-life application for the future. Furthermore, the roles ICTs play in the educational system can be pedagogical, cultural, social, professional and administrative (Ghavifekr et al., 2014). Therefore, ICT should be utilized well and not be seen as a burden among the language teachers. On the other hand, ICT becomes a helping hand to nurture not only the learners', but also the teachers' creativity to enhance their teaching and learning.

ICT provides a variety of learning opportunities for students to learn language (Melor 2007, cited in Melor et al. 2009). This is in line with what Carmen et al. (2003) as cited in Raman and Yamat (2014) stating that students' learning competencies can be enhanced by integrating ICT and it can provide opportunities for communication among learners. In other words, the communication and interaction will not stop in the class since ICT can facilitate such activities regardless where the students and teachers are.

With the integration of ICT to create learning media, in this study using VideoScribe, learning can take place anywhere anytime. Normally the students just read the book as a preparation for the face-to-face meeting.
Now they can watch video created by the lecturer at home with the support of technology advancement, specifically in this study using VideoScribe. As a result, they can access it anytime. Moreover, the video is accompanied with voice where the material is clearly explained. Therefore, the students can comprehend the lesson and ready for more discussion in the face-to-face meeting.

\section{VideoScribe in Language Learning}

VideoScribe is an attractive and interactive new form of storytelling which replicates a 'stop-motion capture style'. Created by Sparkol, VideoScribe allows users to design this style of animated videos quickly and easily (Manchester Metropolitan University). Furthermore, VideoScribe is an interactive ICT platform technology, which can be rendered as video and use in in teaching and learning process. The software can be used the same as using PowerPoint in lesson, yet it provides more opportunities for learners to use them in learning process. Therefore, using interactive ICT platforms allow learners to grab the opportunities for immediate feedback, which can, for example, be used to making drill and practice learning more engaging and effective (Gryzelius, 2015). By using VideoScribe in lesson, it can garner more interest among the learners as they feet closely related to ICT.

A numerous advantages of VideoScribe offers to enhance language learning. Firstly, it can motivate students and also teaches language that is useful. Secondly, it can add variety to the classroom, so that more than one method can be used to present language teaching which in turn makes a class more meaningful and enjoyable. In fact, many visual learners find this application beneficial because it can be 
viewed more than once, not only in the classroom but also in the outside of the classroom. In other words, learners can study anywhere anytime. Auditory learners also benefit in that the learners can listen to the application more than once because this application also contains audio which enables students to listen to the explanation as often as they wish.

Using VideoScribe can further be employed to facilitate learning activities not only learners but also teachers as educators. This application creates a material lesson which is easy to help the learners in teaching and learning process. Teacher can add a fun letter, an image and a picture. Furthermore, the downside to this application is the user can slow the video down to make it easier for students to understand what they have been learning.

The learning media developed in this study can be defined as various components of the learning environment that help students to learn (Gagne in Asyhar 2012: 7). There are so many media that can be used by lecturers, and one of them is an animated video using VideoScribe. There have been several studies in relation to the use of VideoScribe in language teaching and learning. Previous research by Aryuntini, Astuti, \& Yuliana (2018) and Sessu, Sahlan \& Laepe (2018) has demonstrated that VideoScribe-based learning media can improve student learning outcomes. Furthermore, VideoScribe-based learning media is appropriate to be a learning medium (Nurjanah et al., 2017: 230).

Most research regarding the use of VideoScribe has been carried out for the students in junior and senior high school level. Therefore, this study tries to fill the gap by focusing on developing learning media using VideoScribe for university level especially for non-English Department students.

\section{METHOD}

This research employs Research and Development (R\&D) method since it creates a specific product as well as tests the effectiveness (Sugiyono, 2016). The product created in this research is a learning media using VideoScribe for the subject of Present Continuous Tense. In developing the learning media, the research refers to ADDIE development models which consists of five stages, namely Analysis, Design, Development, Implementation, and Evaluation. The research was carried out in Universitas Muhammadiyah Riau in OctoberDecember 2018 involving 35 undergraduate students enrolling in General English subject in odd semester.

\section{Research Procedures}

a. Analysis

The first procedure in this research is needs analysis. It was carried out to figure out the problem and solution. In doing so, learning observation was done to formulate the competence the students had to acquire.

b. Design

The second phase is design which aims to determine the design development, assessment and design framework of learning media products to be developed. In this case, compile the design of instructional media structures and compile learning media interface designs that would be developed.

c. Development

The third stage is development. In this phase, the creation and 
incorporation of content that had been designed at the design stage was carried out. In this phase, inserting the content and adding audio were required.

\section{d. Implementation}

The fourth phase is implementation. It is a concrete step to implement the use of developed learning media. Everything that had been developed was installed or set in such a way as to be appropriate for its role or function to be implemented. The implementation phase of this research was carried out by testing the media directly and filling out a questionnaire by the students. The media trial was carried out in two stages, namely: the first stage of validity testing by subject content experts, learning media experts. The second stage of practicality testing by the students enrolling in General English subject. The results of this trial serve as the basis for carrying out the evaluation phase.

\section{e. Evaluation}

The last research procedure is evaluation. The evaluation was carried out formative evaluation aimed at revision needs. Based on the results of expert reviews and field trials that have been carried out at the implementation stage, there are then two data analysis stages, namely qualitative and quantitative data analysis.

\section{Collecting Data}

In collecting the data, product trials were conducted to obtain data that would be used to revise the development of instructional media in this study. The stages in the design of the learning product trial in this study are as follows: a. Alpha testing

Alpha testing for learning media using VideoScribe was carried out by material experts, media experts and software engineering experts. Alpha testing was conducted to identify and eliminate products, conformity with objectives, material, interactivity and interface. Furthermore, appraisal and input suggestions from material experts and media experts would be used as a basis for revising the initial product produced before being tested.

b. Beta testing

After the product revision phase was carried out, the next step was to test the product in small groups. A small group trial was conducted which involved 35 students. The students enrolled in General English subject at Universitas Muhammadiyah Riau. The subject is a mandatory for all freshmen and the course is 2 credits meeting once a week. The results of the small group trials in the form of suggestions became the basis for product revisions that would be tested at a later stage.

\section{Data Analysis}

Since this research, on the development of instructional media in the subject of Present Continuous Tense at Universitas Muhammadiyah Riau, is a descriptive research, the data analysis used in this study employs descriptive statistical analysis. Data obtained through a questionnaire by media experts, material experts and respondents in the form of qualitative values were converted into quantitative values in accordance with existing scoring rules as seen in the following two tables: 
Table 1. Rules for Granting the Score of Instruments for Media Experts and Material Experts

\begin{tabular}{cc}
\hline Description & Score \\
\hline Very Good & 5 \\
Good & 4 \\
Pretty Good & 3 \\
Not Good & 2 \\
Very Poor & 1 \\
\hline
\end{tabular}

Table 2. Rules for Grading Respondents' Instrument Score Remarks

\begin{tabular}{cc}
\hline Description & Score \\
\hline Strongly Agree & 5 \\
Agree & 4 \\
Quite Agree & 3 \\
Disagree & 2 \\
Strongly Disagree & 1 \\
\hline
\end{tabular}

A Likert scale was utilized for the assessment of every aspect of the product developed where the product can be said to be feasible if the average of each assessment at a minimum gets good criteria. Descriptive analysis was used in analyzing the data obtained.

\section{FINDINGS AND DISCUSSION}

In this section, the author presents the learning media created by using VideoScribe along with the underpinning theory, the sample activities done by the students, how the video is used to support the teaching and learning process, and the findings in this study.

\section{Learning Media Development}

In creating the multimedia exemplar, the author used VideoScribe because it has excellent features such as handwritten drawings, voice, image, and many more. Using video with handwritten drawings just make the material more real. It is different from
PowerPoint the author usually uses where during the presentation, students just see static written words or animation but not like in real life. The handwritten drawings, while at the same time presenting spoken words through narration, can make the presentation more interactive.

As mentioned previously, the students get new learning experience through the video. They can access it anytime and watch it before face-to-face meeting. It means that they can learn independently, especially before faceto-face meeting because the video is accompanied with explanation. As a result, they can become what Hedge (2000: 76) calls 'self-directed learner'. Also, they can practice their writing skill by commenting on YouTube.

Since the students can access the material before the face-to-face learning, they are more prepared for the face-to-face activities. They have more understanding about the lesson, and will use the time in the classroom to strengthen the students' understanding by providing them speaking activity in relation to the use of present continuous.

The video created can be considered interactive because question through narration is included and at the same time writing. This is to engage the students by asking such question. Therefore, they are expected not only to listen, but also to participate by following the video. In addition, the students can also practice their listening skill because voice is included. Another good thing is the students can pause anytime when they cannot understand clearly.

In designing the video, the principles by Mayer (2009) are used. The author includes words and graphics because as Mayer (2009) said, "People learn more deeply from words and 
graphics than from words alone". The words are spoken through narration and printed using the handwritten feature that VideoScribe provides. In order to make the material effective, the author uses the principles by Mayer (2009) especially about signaling, spatial contiguity, and temporal contiguity.

\section{Signaling: Highlight essential material}

Mayer (2009) points out that highlighting important information can make the learners learn efficiently. In doing so, several ways are done such as using headings, arrows, etc. Figure 1, 2, 3 and 4 are examples how signaling principle when designing the video is used. All of the figures are taken from the video created.

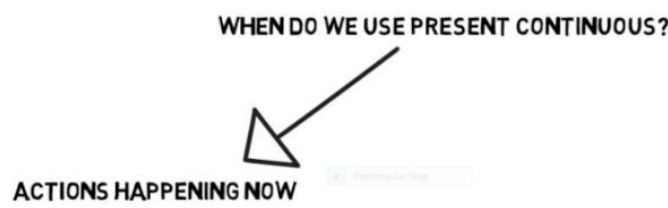

Figure 1: Using heading and arrow for signaling

As seen in Figure 1, heading and arrow are used to signal the point being made. Again, the author is explaining though narration while writing the point.

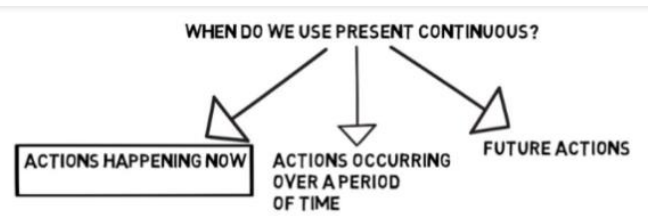

Figure 2. Using heading and arrow for signaling

In Figure 2, the authors emphasizes the focus of the material, out of the other two (actions occurring over a period of time and future actions) because the highlighted point is the material the students focus for the session. By doing so, the learners are expected to pay attention and know exactly what to expect in the lesson. While highlighting the point, the author is also narrating it, "But for this session, we just focus on actions happening now".

Let us have a look at another figure how the important point is highlighted as follows:

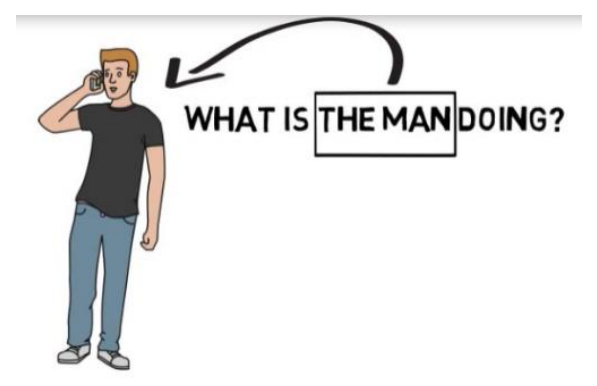

Figure 3. Using heading and arrow for signaling

In the above figure, it can be seen that arrow is used to highlight the point being made. By signaling and using spoken words, the author wants the learners to pay attention to it and hopefully it can make them understand better "You see here, the subject of the sentence is the man". The following figure is another example how the author applies signaling principle when designing the multimedia material for the students.

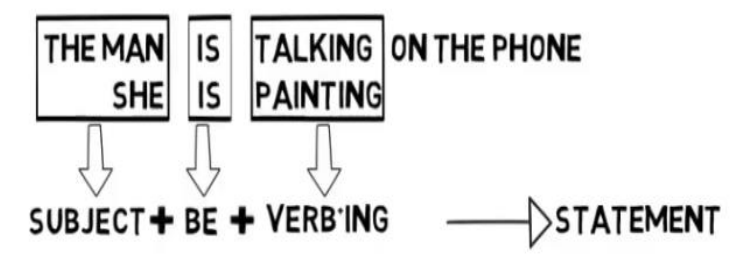

Figure 4. Using heading and arrow for signaling 
Spatial contiguity: Place printed words near corresponding part of graphic

Mayer (2009) suggests, "spatial

contiguity helps learners build connections between corresponding words and graphics".

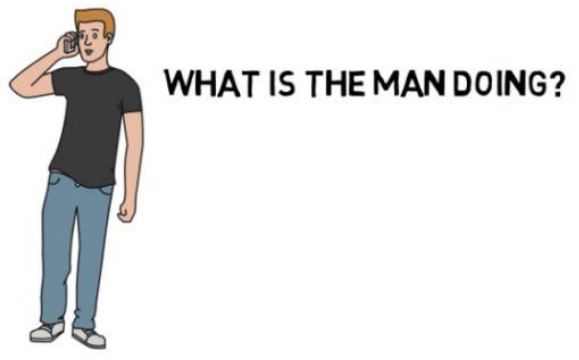

Figure 5. Words near corresponding part of graphic

As seen in Figure 5, the authors places the words next to the picture and says, "Let's look at this picture. As you can see, there is a man. Now if I ask you, what is the man doing?". By showing the picture and placing the corresponding words while at the same time speaking to describe the written words, the author wants to help learners understand the material better.

Temporal contiguity : Present spoken words at same time as corresponding graphics

This principle is also important in order to make the learning effective. In doing so, the author plays as a 'storyteller' (Laurillard, 1995) to explain the points being made. Therefore, in many parts of the video, the author is talking while writing (the words or graphics appear on the screen).

\section{Sample teaching and learning activities}

When learning present continuous, the author assumes the students have mastered the use of be (am, is, are) as well as how to create questions with wh-questions because the students learn it in the previous meeting. Below is the sample teaching and learning activity using an animated video through VideoScribe:

Topic: Present Continuous

\section{Before face-to-face meeting:}

The lecturer uploads the video on YouTube and encourages the students to watch it. If possible, they can give comment using the YouTube comment feature. In this way, they can also practice their writing skill. But the lecturer has to ensure they know how to do it. If the students cannot access the video on YouTube for some reason, the lecturer can copy the video into their laptop so they can watch it at home.

\section{In the classroom}

In teaching the lesson, the lecturer often uses 'presentation, practice, and production' (Hedge, 2000). The material is presented using the video, allowing the students to practice (several parts of the video can be paused), and ask the students to work in pair creating a dialogue. Then they will act it out in front of the class.

At the beginning of the lesson, the students are asked whether they have watched the video or not. More importantly, have they understood the lesson? If they got difficulty or even did not understand at all, perhaps due to their low level of English, the lecturer has to go through the video from the beginning and discuss it with the students. If they have understood everything, it means the lecturer can use the face-to-face meeting just to strengthen their knowledge by providing more exercises which allow them to speak English using present continuous tense. However, in the scenario of this paper, the lecturer assumes the students do not really 
understand the material well. Therefore, the video is used to present the material.

The following is an example how the material is presented which allows the students to practice:

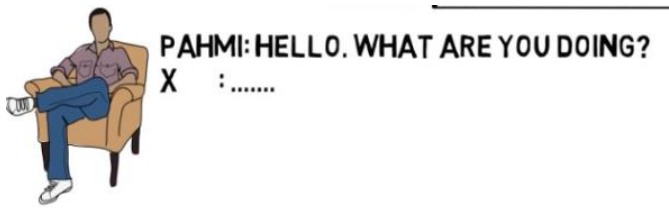

Figure 6. Example of teaching activity

The lecturer will pause this scene to allow the students to fill in the blank orally based on what they see in the picture. Then the answer is provided. However, the lecturer should emphasize that the students are free to say any sentence as long as it is still related to the activity they see based on the picture. For example, they might say, "I am relaxing", "doing nothing, just sitting", etc. The next thing the lecturer will do while presenting the material is to ask the students to practice noticing present continuous form in a sample conversation.

The following scene is the example.

SAMPLE CONVERSATION

PAHMI : HI VELA. WHAT ARE YOU DOING?

VELA : HI PAHMI.I AM WATCHING TV. YOU?

PAHMI : | AM READING ANOVEL

Figure 7. Example of teaching activity

In this scene, the students are required to identify any sentence in present continuous form. After presenting the material through the video, an exercise is given as seen below:

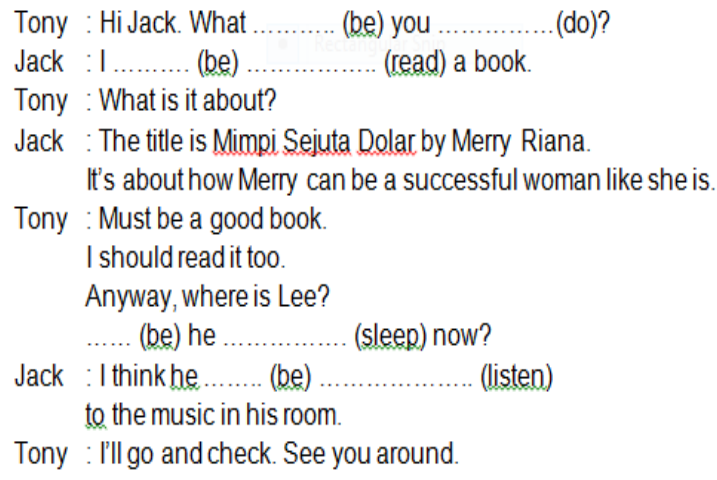

Figure 8. Sample exercise

After completing this exercise, the students will work in pair. They have to create a conversation using present continuous. They are free to make the situation. For example, they might create a phone conversation, a conversation in a library, restaurant, etc. While the students are creating their conversation, the lecturer plays his role as what Harmer (1991) in Hedge (2000) calls 'resource' in case some students need some help. They might ask the lecturer to provide some English words, want to make sure the ing form of certain verbs, etc. Then after a few minutes of preparation, each group will act in front of the class.

\section{Material Expert Validation}

Validation was done by providing learning media products with a scale of 5 questionnaires to be assessed with 14 items of assessment. Before getting the final assessment, there was a revision made twice. The assessment carried out by material experts in detail consists of 14 points of assessment where 4 aspects get a score of 5 (very good) and 10 aspects get a score of 4 (good). Overall, the feasibility test with material experts get a score of 60 with an average score of 4.26 in the very good category. The details can be seen in the table below: 
Table 3. Results of Expert Validation of Material in Every Aspect

\begin{tabular}{|c|c|c|c|}
\hline No & Assessment & Mean & Category \\
\hline 1 & $\begin{array}{l}\text { Aspect of } \\
\text { Cognition } \\
\text { Content }\end{array}$ & 4,33 & $\begin{array}{l}\text { Very } \\
\text { Good }\end{array}$ \\
\hline 2 & $\begin{array}{l}\text { Aspect of } \\
\text { Information } \\
\text { Presentation }\end{array}$ & 4,25 & $\begin{array}{l}\text { Very } \\
\text { Good }\end{array}$ \\
\hline
\end{tabular}

\section{Media Expert Validation}

Validation was carried out by providing learning media products with a scale of 5 questionnaires to be assessed with 15 items of assessment items. Before getting the final assessment, there were two revisions made. In the revision phase I, the assessment carried out by media experts has not yet reached the desired category limit of "Good" in which the results of the initial assessment get a total of 48 with an average of 3.2 (Pretty Enough category). The details can be seen in the following table:

Table 4. Results of Expert Validation of

\begin{tabular}{|c|c|c|c|}
\hline No & Assessment & Mean & Category \\
\hline 1 & $\begin{array}{l}\text { Ease of } \\
\text { Navigation }\end{array}$ & 5 & $\begin{array}{l}\text { Very } \\
\text { Good }\end{array}$ \\
\hline 2 & $\begin{array}{l}\text { Aspect } \\
\text { Media } \\
\text { Integration }\end{array}$ & 4,5 & $\begin{array}{l}\text { Very } \\
\text { Good }\end{array}$ \\
\hline 3 & $\begin{array}{l}\text { Aspect } \\
\text { Artistic and } \\
\text { Aesthetic }\end{array}$ & 5 & $\begin{array}{l}\text { Very } \\
\text { Good }\end{array}$ \\
\hline 4 & $\begin{array}{l}\text { Aspect } \\
\text { Overall } \\
\text { Function } \\
\text { Aspect }\end{array}$ & 4,5 & $\begin{array}{l}\text { Very } \\
\text { Good }\end{array}$ \\
\hline
\end{tabular}

\section{Trial with the Students}

Beta testing was done on 35 undergraduate students taking General English subject in odd semester at Universitas Muhammadiyah Riau. The results show that the 3rd assessment item on the aspect of Cognition Content, in the form of "This learning media makes it easy for me to complete the task effectively" shows the total score of 122 with an average score of 3.94 in good category. The details can be seen below:

Table 5. Student Respondent Validation

\begin{tabular}{|c|c|c|c|}
\hline \multicolumn{3}{|c|}{ Results } & \multirow[b]{2}{*}{ Category } \\
\hline No & Assessment & Mean & \\
\hline 1 & $\begin{array}{l}\text { Aspect of } \\
\text { Cognition } \\
\text { Content }\end{array}$ & 4,17 & Good \\
\hline 2 & $\begin{array}{l}\text { Aspect of } \\
\text { Information }\end{array}$ & 4,31 & Very Good \\
\hline 3 & $\begin{array}{l}\text { Presentation } \\
\text { Ease of }\end{array}$ & 4,23 & Very Good \\
\hline & $\begin{array}{l}\text { Navigation } \\
\text { Aspect }\end{array}$ & & Very Good \\
\hline 4 & $\begin{array}{l}\text { Artistic and } \\
\text { Aesthetic } \\
\text { Aspect }\end{array}$ & 4,39 & Very Good \\
\hline 5 & $\begin{array}{l}\text { Overall } \\
\text { Function } \\
\text { Aspect }\end{array}$ & 4,22 & \\
\hline
\end{tabular}

\section{CONCLUSION}

Based on the research findings and discussion, it can be concluded that the learning media developed has successfully passed the alpha and beta testing regarding its feasibility. It can affirm that the animated video using VideoScribe can be a good tool to enrich the learning process since VideoScribe offers many useful features which in turn motivate the students in learning English. The video created is expected to provide new learning opportunity for the students in terms of self-access. The video is also useful because the students can watch it at home and at the same time listen to the explanation. But again, some support should be provided in order to make sure that the students understand the material well.

Specifically in teaching grammar, the teacher can make use of 
such animated video to attract students' attention. Once they become interested, the lesson mastery can be a lot easier for the students. In other words, making use of media such as VideoScribe can overcome the issue faced by many students regarding the difficulty of learning grammar. Finally, the students are expected to speak English in a correct way.

\section{Suggestion}

In this study, the author VideoScribe for the subject of Present Continuous Tense. Other teachers can try to create their own animated video for other lessons. However, the teachers need to make sure that they really understand how to use the software first. In addition, the current study only develops the learning media. Therefore, future research might focus on finding out the effectiveness of applying the media to improve students' learning outcomes especially those who are from non-English Department students. Another area to be examined for further research is regarding the perceptions and challenges faced by both lecturer and university students in using VideoScribe in language teaching and learning, especially in relation to grammar.

\section{BIBLIOGRAPHY}

Aryuntini, N., Astuti, I., \& Yuliana, Y. G. S. (2018). Development of Learning Media Based on VideoScribe to Improve Writing Skill for Descriptive Text of English Language Study. JETL (Journal Of Education, Teaching and Learning), 3(2), 187. https://doi.org/10.26737/jetl.v3i2.7 46.

Asyhar, Rayandar. (2012). Kreatif Mengembangkan Media
Pembelajaran. Jakarta: Referensi Jakarta.

Azar, B. S., \& Hagen, S. A. (2017).

Understanding and Using English

Grammar (Fifth Edition). New

York: Pearson Education ESL.

Ghavifekr, S., Razak, A. Z. A., Ghani, M. F. A., Ran, N. Y., Meixi, Y., \& Tengyue, Z. (2014). ICT Integration in Education: Incorporation for Teaching \& Learning Improvement. Malaysian Online Journal of Educational Technology,2(2), 24-45.

Gryzelius. J. (2015). ICT in Classroom Learning: Exploring the Discrepancies Between Ideal Conditions and Current Malaysian Policy. Retrieved from http://ideas.org.my/wpcontent/uploads/2015/02/2015022 6-PI18-ICT-in-ClassroomEducation-FINAL.pdf.

Guterres, C., \& Soares, F. (2017). THE

USE OF DICE GAME TO

IMPROVE STUDENTS ABILITY

IN SIMPLE PAST TENSE TO THE

FIRST GRADE STUDENTS OF

SECONDARY SCHOOL IN

TIMOR - LESTE. 1(1), 164-175.

Hedge, T. (2000). Teaching and Learning in the Language Classroom. Oxford: Oxford University Press.

Heryanti, R., Sucipto, M., \& Makmur, M. (2017). THE ANALYSIS OF COMMON GRAMMATICAL ERRORS IN WRITING NARRATIVE ESSAY OF ENGLISH STUDY PROGRAM STUDENTS AT JAMBI UNIVERSITY. Edukasi: Jurnal Pendidikan Dan Pengajaran, 4(2), 83-92.

Jones, R. H., \& Lock, G. (2010).

Functional Grammar in the ESL Classroom. Functional Grammar in the ESL Classroom, 10, 164- 
169.https://doi.org/10.1057/978023 0297524.

Laurillard, D. (1995). Multimedia and the changing experience of the learner. British Journal of Educational Technology, 26(3), 179-189.

Mappiasse, S. S., \& Sihes, A. J. Bin. (2014). Evaluation of English as a Foreign Language and Its Curriculum in Indonesia: A Review. English Language Teaching, 7(10), 113-123.

Mayer, R. E. (2009). Multimedia learning $\left(2^{\text {nd }}\right.$ ed). New York: Cambridge University Press.

Megawati, E. (2019). Penggunaan Model Pembelajaran Peer Teaching dalam Pengajaran Tenses pada Mahasiswa EFL. Deiksis, 11(01), 39. https://doi.org/10.30998/deiksis.v1 $1 \mathrm{i} 01.3076$

Melor Md Yunus. (2009). Malaysian ESL teachers' use of ICT in their classrooms: Expectations and realities. European Association for Computer Assisted Language Learning. ReCALL, 19(1), 79-95.

Nordin, N., Embi, M. A., \& Yunus, M. M. (2010). Mobile learning framework for lifelong learning. Procedia - Social and Behavioral Sciences, 7, 130-138. http://dx.doi.org/10.1016/j.sbspro. 2010.10.019.

Nurjanah, Fitri. dkk. (2017). Pengembangan Media Animasi Menggunakan Software
Videoscribe pada Materi Minyak Bumi Kelas X MIA di MAN Darussalam. Jurnal Ilmiah Mahasiswa Pendidikan Kimia. Vol. 2 No. 4.

Ong, C. . (2011). Pre-Service Teachers' Beliefs about the Teaching and Learning of Grammar. The English Teacher, XL, 27-47.

Pahmi, P., \& Edjuista, N. (2018). A STUDY ON THE ABILITY OF THE SECOND YEAR STUDENTS OF MADRASAH ALIYAH DAR EL HIKMAH PEKANBARU IN SELECTING CORRECT TROUBLESOME. 3(1).

Raman, K., \& Yamat, H. (2014). Barriers Teachers Face in Integrating ICT during English Lessons: A Case Study. Malaysian Online Journal of Educational Technology, 2(3), 1119.

Richards, J. C., Hull, J., \& Proctor, S. (2017.). Interchange (Fifth edition). New York: Cambridge University Press

Sessu, A., Sahlan., \& Laepe, A. (2018). The Effectiveness Of Video Scribe In Teaching English At SMPN 1 Molawe Konawe Utara. 3(1).

Sugiyono. (2016). Metode Penelitian Kuantitatif, Kualitatif dan $R \& D$. Bandung: Alfabeta. 